\title{
Kemampuan Pemecahan Masalah Matematika: Sebuah Tinjauan terhadap Kepribadian Guardian dan Idealis
}

\author{
Rika Arifah Sari1; Fenny Anggreni2 ${ }^{2 *}$ Mazlan $^{3}$ \\ Alumni Prodi Pendidikan Matematika IAIN Langsa ${ }^{1}$ \\ Dosen Prodi Pendidikan Matematika, IAIN Langsa ${ }^{23}$ \\ fenny@iainlangsa.ac.id*
}

\begin{abstract}
Classification of personality based on the MBTI personality grouped by David Keisey. The purpose of this study was to determine the differences in students' mathematical problem-solving abilities in terms of guardian and idealistic personality types in SMA Negeri 4 vocational youth. This research is qualitative. The subjects of this study were 4 students from class X Mia 3 SMA Negeri 4. The data validity technique used in this research is the triangulation technique. Data analysis techniques include descriptive data of written test results and interview results, analyzed from written test results and interview results, then conclusions are drawn. The results of the discussion can be concluded that there are differences in mathematical problem-solving abilities of guardian and idealist personality types. Guardian personality type subjects can fulfil all problem-solving indicators according to Polya, namely the stages of understanding the problem, planning solutions, solving problems, and re-examining and drawing conclusions properly and correctly, while subjects with idealistic personality types at the stage of understanding the problem do not write down what is asked. In the problem-solving stage, there are errors so that the results obtained are wrong and do not meet one of the Polya indicators, namely not reexamining the existing answers but can draw conclusions. So the researchers suggest that students can improve their mathematical problem-solving skills well.
\end{abstract}

Keywords: Guardian Personality Type, Idealist Personality Type, Solving Ability.

\begin{abstract}
Abstrak
Penelitian ini menggunakan penggolongan berdasarkan kepribadian MBTIyang dikelompokkan oleh David Keisey. Tujuan penelitian ini adalah untuk mengetahui perbedaan kemampuan pemecahan masalah matematika siswa ditinjau dari tipe kepribadian guardian dan idealis di SMA negeri 4 kejuruan muda. Penelitian ini merupakan penelitian kualitatif. Subjek penelitian ini adalah 4 peserta didik dari kelas X Mia 3 SMA Negeri 4 Kejuruan Muda. Teknik keabsahan data yang digunakan dalam penelitian ini adalah triangulasi teknik. Teknik analisa data meliputi, data deskripsi hasil tes tertulis dan hasil wawancara, dianlisa dari hasil tes tertulis dan hasil wawancara, kemudian ditarik kesimpulan. Hasil pembahasan dapat disimpulkan bahwa Terdapat perbedaan kemampuan pemecahan masalah matematika subjek tipe kepribadian guardian dan idealis. Subjek tipe kepribadian guardian dapat memenuhi semua indikator pemecahan masalah menurut polya yaitu tahap memahami masalah, merencanakan penyelesaian, memecahkan masalah, dan memeriksa kembali dan menarik kesimpulan dengan baik dan benar, sedangkan subjek dengan tipe kepribadian idealis pada tahap memahami masalah tidak menuliskan yang ditanyakan, pada tahap memecahkan masalah terdapat kesalahan sehingga hasil yang diperoleh salah dan tidak memenuhi salah satu indikator polya yaitu tidak memeriksa kembali jawaban yang ada tetapi dapat menarik kesimpulan. Maka saran
\end{abstract}


peneliti agar peserta didik dapat meningkatkan kemampuan pemecahan masalah matematis dengan baik.

Kata Kunci: Kemampuan Pemecahan Masalah, Kepribadian Guardian, Kepribadian Idealis 


\section{A. Pendahuluan}

Matematika merupakan ilmu yang sangat penting dalam dunia pendidikanmulai dari Sekolah Dasar sampai Perguruan Tinggi. Pada tingkat SD dan SMA, SKL menyatakan bahwa salah satu tujuan pembelajaran matematika yaitu pemecahan masalah yang meliputi kemampuan (1) memahami masalah, (2) merancang model matematika, (3) menyelesaikan model, dan (4) menafsirkan solusi yang diperoleh, sehingga diperlukan peserta didik agar dapat mencapai kemampuan yang tersebut di atas. Dengan hal ini dapat dikatakan bahwa pembelajaran pemecahan masalah dapat memenuhi salah satu standar kompetensi lulusan mata pelajaran matematika (Depdiknas, 2006).

Selanjutnya di dalam Peraturan Menteri Pendidikan Nasional Republik Indonesia Nomor 22 Tahun 2006 tentang Standar Isi pada butir kelima yang sangat memperkuat aspek psikologis dalam pembelajaran matematika menyebutkan bahwa pembelajaran matematika bertujuan agar peserta didik memiliki sikap menghargai kegunaan matematika dalam kehidupan, yaitu, memiliki rasa ingin tahu, perhatian, dan minat dalam mempelajari matematika, serta sikap ulet, dan percaya diri dalam pemecahan masalah (Permendiknas, 2006).

Pemecahan masalah menjadi penting dalam tujuan pendidikan matematika disebabkan karena dalam kehidupan sehari-hari manusia memang tidak pernah dapat lepas dari masalah. Aktivitas memecahkan masalah dapat dianggap suatu aktivitas dasar manusia.Masalah harus dicari jalan keluarnya oleh manusia itu sendiri, jika tidak mau dikalahkan oleh kehidupan. Pentingnya kemampuan pemecahan masalah oleh siswa dalam dalam matematika dikemukakan oleh branca bahwa kemampuan pemecahan masalah merupakan tujuan umum pengajaran matematika, pemecahan masalah merupakan proses inti dan utama dalam kurikulum matematika.dan kemampuan pemecahan masalah merupakan kemampuan dasar dalam belajar matematika (Mahuda, 2012). 
Fakta hasil wawancara peneliti dengan salah satu guru bidang studi matematika kelas X di SMA Negeri 4 Kejuruan Muda menyatakan bahwa terkadang siswa tidak mampu menyelesaikan permasalahan soal matematika yang diberikan oleh guru. Hal itu disebakan oleh beberapa faktor seperti metode pembelajaran, strategi pembelajaran, motivasi belajar, serta siswa yang tidak memperhatikan guru ketika guru sedang menjelaskan pelajaran di depan kelas. Dan ketika siswa tersebut tidak mengerti dengan pelajaran yang diberikan oleh guru tersebut, siswa tersebut tidak bertanya mengenai hal yang tidak diketahuinya. Sehingga ketika guru tersebut memberikan soal maka siswa tersebut tidak dapat menyelsaikan soal yang diberikan dengan baik atau siswa tersebut tidak mampu memecahkan masalah yang ada di soal tersebut.

Hal ini sangat berdampak buruk untuk kelangsungan belajar siswa, hal ini dikarenakan kemampuan pemecahan masalah menjadi salah satu kompetensi yang harus dikembangkan siswa pada materi-materi tertentu. Untuk mengembangkan kemampuan pemecahan masalah tersebut tentunya bukanlah yang mudah, dikarenakan hal itu harus di mulai dari akar permasalahan yang ada. Untuk itu dibutuhkannya metode mengajar yang tepat serta hubungan yang baik antara guru dan siswa dalam suatu kegiatan belajar mengajar agar siswa termotivasi untuk mengembangkan kemampuan pemecahan masalah dengan soal-soal yang diberikan oleh guru tersebut.

Dengan metode mengajar yang disesuaikan berdasar proses berpikirnya, maka diharapkan proses mengajar belajar dapat menyentuh siswa lebih secara pribadinya, karena memang sudah seharusnya siswa mempunyai hak untuk diperhatikan oleh setiap pengajar secara pribadi masing-masing, dan bukan hanya secara klasikal, di mana banyak pribadi bergabung menjadi satu. Marpaung menyatakan bahwa cara siswa belajar dan cara berpikir siswa berbeda, dimana perbedaan tersebut paling mudah diamati dalam tingkah laku secara nyata (Marpaung, 2001). Perbedaan tingkah laku pada setiap individu, peserta didik terjadi karena pengaruh dari kepribadian yang berbeda-beda. 
Berasal dari kenyataan, bahwa kepribadian manusia itu sangat bermacam-macam, bahkan mungkin sama banyak dengan banyaknya orang, tipe tertentu, karena mereka berpendapat bahwa cara itulah yang paling efektif untuk mengenal sesama manusia dengan baik. Pada tahun 1984 dalam bukunya Please Understand Me I dan II, David Keirsey, seorang professor dalam bidang psikologi dari California State University, menggolongkan kepribadian menjadi 4 tipe, yaitu Guardian, Artisan, Rational, dan Idealis.

Penggolongan yang dilakukan oleh David Keirsey ini berdasarkan pemikiran bahwa perbedaan nyata yang dapat dilihat dari seseorang adalah tingkah laku (behaviour). Tingkah laku dari seseorang merupakan cerminan hal yang nampak dari apa yang dipikirkan dan dirasakan oleh orang tersebut. Implikasi dari pernyataan ini adalah, kalau seseorang hendak mengetahui hal yang dipikirkan oleh orang lainnya, dapat dibaca melalui tingkah lakunya.

Dalam dunia pendidikan, untuk mengetahui pemikiran seorang peserta didik mengenai pengerjaannya terhadap soal tertentu, tentunya bukan dilihat dari tingkah lakunya, akan tetapi secara spesifik dari hasil pekerjaan peserta didik. Untuk dapat mengetahui pemikiran seorang peserta didik, salah satunya dapat dengan cara mengajak peserta didik untuk berdiskusi dengan pengajar, sehingga peserta didik mau mengatakan apa yang ada dalam pemikirannya pada saat mengerjakan soal tertentu.

Hasil belajar tersebut juga menujukkan bagaimana cara siswa berfikir dengan kepribadian yang berbeda-beda. Tentunya setiap siswa menginginkan hasil belajar dengan nilai yang baik walaupun dengan perbedaan kepribadian yang ada. Perbedaan kepribadian yang sangat mencolok adalah siswa yang berkepribadian yang guardian dan idealis. Siswa yang memiliki tipe guardian menyukai kelas dengan model tradisional beserta prosedur yang teratur. Siswa dengan tipe ini menyukai pengajar yang dengan gamblang menjelaskan materi dan memberikan perintah secara tepat dan nyata, materi harus diawali pada kenyataan nyata. Berbeda dengan tipe idealist yang lebih menyukai untuk menyelesaikan tugas secara pribadi dari pada diskusi kelompok, dapat 
memandang persoalan dari berbagai perspektif, mampu mengembangkan ide yang dimiliki secara luas dan percaya akan kemampuan yang dimiliknya.

\section{B. Metode}

Penelitian ini di laksanakan di SMA Negeri 4 Kejuruan Muda, yang beralamat di Jln Alur Meranti Desa Sungai Liput, Kec. Kejuruan Muda, Kab.Aceh Tamiang. Penelitian ini menggunakan metode deskriptif dengan pendekatan kualitatif. Pendekatan kualitatif yang digunakan dalam penelitian ini bertujuan untuk mendapatkan gambaran berkaitan dengan angka atau statistik mengenai perbedaan kemampuan pemecahan masalah matematika ditinjau dari tipe kepribadian guardian dan idealis (Riduwan, 2010).

Dalam penelitian ini untuk mengetahui subyek yang akan diteliti maka peneliti akan meneliti siswa-siswi kelas X SMA Negeri 4 Kejuruan Muda, kemudian peneliti meminta pendapat kepada salah seorang guru mata pelajaran matematika kelas X untuk memilih 1 kelas yang akan menjadi bahan penelitian untuk peneliti, setelah direkomendasikan oleh guru matematika tersebut maka kelas yang terpilih yang akan menjadi kelas penelitian adalah kelas peminatan X Mia 3.

Prosedur pemilihan subjek dalam penelitian ini, yaitu: (a) Menyiapkan angket atau kuisioner MBTI (Myer-Brigs Type Indicator), (b) Memberikan angket atau kuisioner MBTI kepada siswa-siswi kelas X Mia 3 yang telah terpilih, (c) Menentukan siswa berdasarkan dimensi kepribadian Myer-Briggs, (d) Mengelompokkan siswa berdasarkan penggolongan kepribadian berdasarkan David Keirsey, (e) Memilih 4 subjek penelitian, 2 subjek dengan tipe kepribadian guardian dan 2 subjek dengan tipe idealis.

Adapun metode pengumpulan data dalam penelitian ini adalah angket, tes soal dan wawancara. Instrumen penelitian yang di gunakan yaitu angket soal MBTI, tes soal pemecahan masalah dan pedoman wawancara. 


\section{Hasil dan Pembahasan}

Adapun hasil penelitian siswa kelas X SMA Negeri 4 Kejuruan Muda yang ditinjau dari tipe kepribadian Myer Briggs Type Indicator (MBTI). Data yang disajikan diperoleh dari penelitian yang dilakukan terhadap empat kelompok subjek. Subjek tersebut dipilih berdasarkan tipe kepribadian MBTI.Penentuan kelompok subjek penelitian didasarkan pada hasil penyebaran tes kepribadian Myer Briggs Type Indicator (MBTI) yang telah diisi oleh oleh peserta didik kelas X-MIA 3 SMA Negeri 4 Kejuruan Muda yang terdiri dari 36 peserta didik. Sebagaimana tabel 1 di bawah ini:

Tabel 1 Jumlah Peserta Didik Tes Tipe Kepribadian MBTI

\begin{tabular}{cccccc}
\hline Kelas & \multicolumn{4}{c}{ Tipe Kepribadian MBTI } & Jumlah \\
\cline { 2 - 5 } & Guardian & Artisan & Rational & Idealis & \\
\hline X - MIA 3 & 29 & 3 & 2 & 2 & 36 \\
\hline
\end{tabular}

Dari hasil tes kepribadian menunjukkan bahwa pada kelas X - MIA 3 terdapat 29 peserta didik dengan tipe kepribadian Guardian, 3 peserta didik dengan tipe Artisan, 2 peserta didik dengan tipe kepribadian Rational, dan 2 peserta didik dengan tipe kepribadian Idealis. Subjek pada penelitian ini hanya di ambil empat subjek yaitu 2 subjek dengan tipe kepribadian Guardian dan 2 subjek dengan tipe kepribadian Idealis.Pengambilan subjek penelitian ini berdasarkan hasil tes kepribadian MBTI dan dan atas hasil rekomendasi dari guru pengampu mata pelajaran matematika. Adapun subjek penelitian yang diperoleh sabagaimana tercantum dalam tabel 2 di bawah ini:

Tabel 2. Subjek Penelitian

\begin{tabular}{lcc}
\hline No & Kode Subjek & Tipe Kepribadiaan Subjek \\
\hline 1. & LA & Guardian \\
2. & AF & Guardian \\
3. & TI & Idealis \\
4. & AL & Idealis \\
\hline
\end{tabular}

Tabel 2 memperlihatkan nama subjek, inisial subjek dan jenis tipe kepribadian yang dimiliki oleh subjek LA adalah tipe kepribadian Guardian, yang miliki AF adalah tipe kepribadian Guardian, yang dimiliki TI adalah tipe 
kepribadian Idealis, dan yang dimiliki AL adalah tipe kepribadian Idealis. Subjek penelitian yang terpilih kemudian diminta untuk menyelesaikan tes tertulis agar mengetahui kemampuan pemecahan masalah matematis peserta didik, kemudian setelah tes tertulis dilaksanakan dilanjutkan dengan tes wawancara pada masing-masing subjek. Hasil pengerjaan tes tertulis dan hasil wawancara peserta didik yang menjadi data untuk dianalisis.

Data tersebut diuraikan menurut langkah pemecahan masalah matematis menurut polya yang meliputi memahami masalah, merencanakan penyelesaian, menyelesaikan masalah, memeriksa kembali hasil yang diperoleh dan menarik kesimpulan. Selanjutnya data dianalisis berdasarkan kepribadian subjek dan kemampuan pemecahan masalah yang diberikan.

Pemecahan masalah matematis adalah pemecahan masalah yang memerlukan tahap-tahap yang dilakukan siswa secara matematis berdasarkan tes angket MBTI yang diberikan kepada siswa kelas X Mia 3 SMA Negeri 4 Kejuruan Muda.Selanjutnya dipilih 4 subjek yaitu 2 subjek siswa dengan tipe kepribadian Guardian dan 2 subjek dengan tipe kepribadian Idealis. Adapun pembahasan dari setiap subjek dapat dinyatakan sebagai berikut:

\section{Kemampuan Pemecahan Masalah Matematis Yang Diperoleh Siswa Dengan Tipe Kepribadian Guardian Inisial LA}

LA dapat menyelesaikan soal yang ada dengan tepat dan benar. Subjek memahami soal dengan membaca secara perlahan dan teliti, ketika subjek memahami kata-katanya kemudian subjek memikirkan bagaimana caranya menyelesaikan soal ini. Pada tahap memahami masalah subjek mampu menuliskan hal apa yang diketahui dengan membuat permisalan dan yang ditanyakan dengan benar. Pada tahap merencanakan penyelesaian mampu merencanakan penyelesaian dengan membuat persamaan-persamaan dengan benar. Pada tahap memecahkan masalah mampu menyelesaikan soal yang ada dengan tepat dan benar walaupun sedikit kebingungan yang dirasakan di awal, tetapi ketika tau langkah pengerjannya maka subjek tidak mengalami 
kesulitan lagi. Pada tahap memeriksa kembali mampu memeriksa kembali jawaban yang ada dengan mengecek ke salah satu persamaan yang ada hingga terbukti benar dan dapat menarik kesimpulan.

Berdasarkan indikator kemampuan pemecahan masalah matematika siswa dalam memecahkan masalah matematika menurut Polya, LA dapat memahami masalah, merencanakan penyelesaian, memecahkan masalah dan memeriksa kembali jawaban dengan baik dan benar walaupun masih terdapat sedikit kebingungan dalam menyelesaikan permasalahan yang ada. Maka subjek mampu memecahkan masalah yang ada dengan baik dan benar.

\section{Kemampuan Pemecahan Masalah Matematis Yang Diperoleh Siswa Dengan Tipe Kepribadian Guardian Inisial AF}

AF dapat menyelesaikan soal yang ada dengan tepat dan benar. Subjek memahami soal dengan membaca soal nya secara teliti kemudian mengingat apa saja yang ada dalam soal itu. Pada tahap memahami masalah subjek mampu menuliskan yang diketahui dan di tanyakan dengan baik. Pada tahap merencanakan penyelesaian mampu merencanakan penyelesaian dengan membuat model matematikanya untuk membantu menyelesaikan soal tersebut. Pada tahap memecahkan masalah mampu menyelesaikan soal yang ada dengan tepat dan benar. Pada tahap memeriksa kembali mampu memeriksa kembali jawaban yang ada dan membuat kesimpulan dengan benar.

Berdasarkan indikator kemampuan pemecahan masalah matematis siswa dalam memecahkan masalah matematika menurut Polya, AF dapat memahami masalah, merencanakan penyelesaian, memecahkan masalah dan memeriksa kembali jawaban dengan baik dan benar walaupun masih terdapat sedikit kebingungan dan ketakutan ada kesalahan dalam langkah-langkah penyelesaiannya dalam menyelesaikan permasalahan yang ada. Maka subjek mampu memecahkan masalah yang ada dengan baik dan benar. 


\section{Kemampuan Pemecahan Masalah Matematis Yang Diperoleh Siswa Dengan Tipe Kepribadian Idealis Inisial TI}

TI dapat menyelesaikan soal yang ada tetapi terdapat kesalahan dalam pengerjaannya. Subjek memahami soal dengan membaca soal secara berulang-ulang kali untuk mengetahui maksud dari soal ini, kalau dijelaskan subjek mengerti, kalau tidak subjek lupa. Subjek pada tahap memahami masalah mampu menuliskan yang diketahui dengan baik tetapi tidak menuliskan yang di tanyakan. Pada tahap merencanakan penyelesaian mampu merencanakan penyelesaian dengan dengan membuat model matematikanya. Pada tahap memecahkan masalah. Subjek dapat menyelesaikan soal yang ada tetapi dalam mengerjakannya terdapat kesalahan sehingga hasil yang diperoleh salah. Pada tahap memeriksa kembali tidak mampu memeriksa kembali jawaban yang ada tetapi dapat membuat kesimpulan.

Berdasarkan indikator kemampuan pemecahan masalah matematis siswa dalam memecahkan masalah matematika menurut Polya TI dapat memahami masalah, merencanakan penyelesaian, memecahkan masalah tetapi dalam mengerjakannya terdapat kesalahan sehingga hasil yang diperoleh salah dan tidakmemeriksa kembali jawaban yang ada. Sehingga subjek tersebut dianggap tidak dapat memecahkan masalah karena dalam mengerjakannya terdapat kesalahan sehingga hasil yang diperoleh salah dan tidak dapat memeriksa kembali jawaban dengan tepat dan benar tetapi dapat menyimpulkan jawaban yang ada. Maka subjek tidak mampu memecahkan masalah yang ada dengan baik dan benar.

\section{Kemampuan Pemecahan Masalah Matematis Yang Diperoleh Siswa Dengan Tipe Kepribadian Idealis Inisial AL}

AL dapat menyelesaikan soal yang ada tetapi terdapat kesalahan dalam pengerjaannya. Subjek memahami soal dengan membaca soal secara berulang-ulang kali. Subjek pada tahap memahami masalah mampu menuliskan yang diketahui dengan baik tetapi tidak menuliskan yang di 
tanyakan. Pada tahap merencanakan penyelesaian mampu merencanakan penyelesaian dengan dengan membuat model matematikanya tetapi terdapat kebingungan apakah harus ada yang di ubah persamaannya atau tidak. Pada tahap memecahkan masalah Subjek hanya dapat memecahkan masalah dengan baik dan benar hanya 1 soal, sedangkan soal yang 1 lagi terdapat kesalahan dalam menyelesaikannya sehingga hasil yang diperoleh salah. Pada tahap memeriksa kembali tidak memeriksa kembali jawaban yang telah ada karena merasa kebingungan, tetapi dapat membuat kesimpulan.

Berdasarkan indikator kemampuan pemecahan masalah matematis siswa dalam memecahkan masalah matematika menurut Polya, AL dapat memahami masalah, merencanakan penyelesaian, memecahkan masalah tetapi dalam mengerjakannya terdapat kesalahan sehingga hasil yang diperoleh salah dan tidak memeriksa kembali jawaban yang ada tetapi dapat menyimpulkan jawaban yang ada. Maka subjek tidak mampu memecahkan masalah yang ada dengan baik dan benar.

Berdasarkan pembahasan di atas dari ke 4 subjek yang ada, dengan 2 subjek bertipe kepribadian guardian dan 2 subjek bertipe kepribadian idealis, berikut tabel perbedaan kemampuan pemecahan masalah menurut indikator Polya:

Tabel 3. Perbedaan Kemampuan Pemecahan Masalah Matematis Tipe Kepribadian Guardian dan Idealis

\begin{tabular}{|c|c|c|c|c|}
\hline \multirow{2}{*}{$\begin{array}{c}\text { Indikator } \\
\text { Pemecahan } \\
\text { Masalah }\end{array}$} & \multicolumn{2}{|c|}{ Tipe Guardian } & \multicolumn{2}{|c|}{ Tipe Idealis } \\
\hline & LA & $\mathbf{A F}$ & TI & AL \\
\hline $\begin{array}{l}\text { Memahami } \\
\text { Masalah }\end{array}$ & $\begin{array}{l}\text { Mampu } \\
\text { membuat yang } \\
\text { diketahui dan } \\
\text { ditanyakan } \\
\text { dengan benar } \\
\text { dan tepat. }\end{array}$ & $\begin{array}{l}\text { Mampu } \\
\text { menuliskan yang } \\
\text { diketahui dan } \\
\text { ditanyakan } \\
\text { dengan benar. }\end{array}$ & $\begin{array}{l}\text { Mampu } \\
\text { menuliskan yang } \\
\text { diketahui dengan } \\
\text { baik tetapi tidak } \\
\text { menuliskan yang } \\
\text { ditanyakan. }\end{array}$ & $\begin{array}{l}\text { Mampu } \\
\text { menuliskan yang } \\
\text { diketahui dengan } \\
\text { baik tetapi tidak } \\
\text { menuliskan yang } \\
\text { ditanyakan. }\end{array}$ \\
\hline $\begin{array}{l}\text { Merencanakan } \\
\text { Penyelesaian }\end{array}$ & $\begin{array}{l}\text { Mampu } \\
\text { merencanakan } \\
\text { penyelesaian } \\
\text { dengan membuat } \\
\text { model } \\
\text { matematika atau }\end{array}$ & $\begin{array}{l}\text { Mampu } \\
\text { merencanakan } \\
\text { penyelesaian } \\
\text { dengan membuat } \\
\text { model } \\
\text { matematikanya. }\end{array}$ & $\begin{array}{l}\text { Mampu } \\
\text { merencanakan } \\
\text { penyelesaian } \\
\text { dengan dengan } \\
\text { membuat model } \\
\text { matematikanya. }\end{array}$ & $\begin{array}{l}\text { Mampu } \\
\text { merencanakan } \\
\text { penyelesaian } \\
\text { dengan dengan } \\
\text { membuat model } \\
\text { matematikanya. }\end{array}$ \\
\hline
\end{tabular}




\begin{tabular}{|c|c|c|c|c|}
\hline \multirow{2}{*}{$\begin{array}{l}\text { Indikator } \\
\text { Pemecahan } \\
\text { Masalah }\end{array}$} & \multicolumn{2}{|c|}{ Tipe Guardian } & \multicolumn{2}{|c|}{ Tipe Idealis } \\
\hline & LA & $\mathbf{A F}$ & TI & AL \\
\hline $\begin{array}{l}\text { Memecahkan } \\
\text { Masalah }\end{array}$ & $\begin{array}{l}\text { persamaan- } \\
\text { persamaan. } \\
\text { Mampu } \\
\text { memecahkan } \\
\text { masalah yang } \\
\text { ada dengan baik } \\
\text { dan benar. }\end{array}$ & $\begin{array}{l}\text { Mampu } \\
\text { memecahkan } \\
\text { masalah yang } \\
\text { ada dengan baik } \\
\text { dan benar. }\end{array}$ & $\begin{array}{l}\text { Dapat } \\
\text { menyelesaikan } \\
\text { soal yang ada } \\
\text { tetapi dalam } \\
\text { mengerjakannya } \\
\text { terdapat } \\
\text { kesalahan } \\
\text { sehingga hasil } \\
\text { yang diperoleh } \\
\text { salah. Maka } \\
\text { subjek tidak } \\
\text { mampu } \\
\text { memecahkan } \\
\text { masalah yang } \\
\text { ada. }\end{array}$ & $\begin{array}{l}\text { Hanya dapat } \\
\text { memecahkan } \\
\text { masalah dengan } \\
\text { baik dan benar } \\
\text { hanya } 1 \text { soal, } \\
\text { sedangkan soal } \\
\text { yang } 1 \text { lagi } \\
\text { terdapat } \\
\text { kesalahan dalam } \\
\text { menyelesaikann } \\
\text { ya sehingga hasil } \\
\text { yang diperoleh } \\
\text { salah. Maka } \\
\text { subjek tidak } \\
\text { mampu } \\
\text { memecahkan } \\
\text { masalah yang } \\
\text { ada dengan baik } \\
\text { dan benar. }\end{array}$ \\
\hline $\begin{array}{l}\text { Memeriksa } \\
\text { Kembali dan } \\
\text { Menarik } \\
\text { Kesimpulan }\end{array}$ & $\begin{array}{l}\text { Mampu } \\
\text { memeriksa } \\
\text { kembali jawaban } \\
\text { yang ada dengan } \\
\text { benar dan dapat } \\
\text { menarik } \\
\text { kesimpulan. }\end{array}$ & $\begin{array}{l}\text { Mampu } \\
\text { memeriksa } \\
\text { kembali jawaban } \\
\text { yang ada dan } \\
\text { membuat } \\
\text { kesimpulan } \\
\text { dengan benar. }\end{array}$ & $\begin{array}{l}\text { Tidak mampu } \\
\text { memeriksa } \\
\text { kembali jawaban } \\
\text { yang ada tetapi } \\
\text { dapat membuat } \\
\text { kesimpulan. }\end{array}$ & $\begin{array}{l}\text { Tidak mampu } \\
\text { memeriksa } \\
\text { kembali jawaban } \\
\text { yang ada tetapi } \\
\text { dapat membuat } \\
\text { kesimpulan. }\end{array}$ \\
\hline
\end{tabular}

Berdasarkan pembahasan di atas, subjek dengan tipe kepribadian guardian dapat memenuhi dan mengerjakan semua indikator pemecahan masalah menurut polya yaitu tahap memahami masalah, merencanakan penyelesaian, memecahkan masalah, dan memeriksa kembali dengan baik dan benar, sedangkan subjek dengan tipe kepribadian idealis pada tahap memahami masalah tidak dapat menuliskan yang ditanyakan, pada tahap merencanakan penyelesaian dapat membuat model-model matematikanya, pada tahap memecahkan masalah tidak dapat memecahkan masalah yang ada dengan baik dan benar, dan tidak memenuhi salah satu indikator polya yaitu tidak memeriksa kembali jawaban yang ada tetapi dapat menarik kesimpulan. Maka terdapat perbedaan kemampuan pemecahan masalah matematika berdasarkan tipe kepribadian guardian dan idealis. 


\section{E. Kesimpulan}

Adapun kesimpulan dari penelitian ini adalah kemampuan pemecahan masalah matematika subjek dengan tipe kepribadian guardian dapat memenuhi dan mengerjakan semua indikator pemecahan masalah menurut Polya. Sementara pada subjek dengan tipe kepribadian idealis terdapat kendala seperti pada tahap memahami masalah tidak dapat menuliskan yang ditanyakan, pada tahap merencanakan penyelesaian mampu membuat model matematikanya, pada tahap memecahkan masalah terdapat kesalahan sehingga hasil yang diperoleh salah, dan tidak memenuhi salah satu indikator Polya yaitu tidak memeriksa kembali jawaban yang ada tetapi dapat menarik kesimpulan. Jadi pada kasus ini, subjek tipe kepribadian idealis tidak mampu memecahkan permasalahan soal system persamaan linear tiga variabel dengan baik dan benar. Jadi terdapat perbedaan kemampuan pemecahan masalah matematika subjek tipe kepribadian guardian dan idealis.

\section{DAFTAR PUSTAKA}

Depdiknas, 2006. Kurikulum Tingkat Satuan Pendidikan. Jakarta: Depdiknas.

Mahuda, I., 2012. Pembelajaran Kooperatif Tipe Co-op Co-op dengan Pendekatan Open Ended untuk meningkatkan Kemampuan Pemecahan Masalah Matematis Siswa SMA Bandung.

Marpaung, Y., 2001. Proses Berpikir Siswa dalam Pembentukan Konsep Algoritma Matematis. Yogyakarta: s.n.

Permendiknas, 2006. Standar Isis Satuan Pendidikan. Jakarta: KemendiknasDepdiknas.

Riduwan, 2010. Belajar Mudah Penelitian untuk Guru Karyawan dan Peneliti Muda. Bandung: Alfabeta. 
